\title{
CONGENITAL JAUNDICE IN RATS, DUE TO A DEFECT IN GLUCURONIDE FORMATION ${ }^{1}$
}

\author{
By RUDI SCHMID,² JULIUS AXELROD, LYDIA HAMMAKER,² AND \\ RICHARD L. SWARM \\ (From the National Institutes of Health, United States Public Health Service, Bethesda, Md.; \\ the Thorndike Memorial Laboratory, and the Second and Fourth (Harvard) Medical \\ Services, Boston City Hospital; and the Department of Medicine, Harvard \\ Medical School, Boston, Mass.)
}

(Submitted for publication March 4, 1958; accepted April 24, 1958)

It has recently been reported that bilirubin is excreted in the bile as a water-soluble glucuronide (1-3). The conjugation of bilirubin is believed to occur mainly in the liver $(4,5)$. In vitro, formation of bilirubin glucuronide has been demonstrated with a system containing liver microsomes as the enzyme source and uridine diphosphate glucuronic acid as the glucuronic acid donor $(5,6)$. Since conjugation of bilirubin appears to be essential for its excretion in the bile, a defect in the glucuronide forming mechanism would result in impaired pigment excretion and, hence, in retention of free bilirubin in the blood.

In preliminary communications $(7,8)$, such defects in glucuronide formation have been reported in congenital nonhemolytic nonobstructive jaundiçe in man (9) and in hereditary nonhemolytic jaundice in rats (10). The present report is concerned with the details of the murine studies, while the human syndrome will be considered in a separate communication.

\section{MATERIALS AND METHODS}

Nonjaundiced Wistar rats, known to be carriers of the jaundice trait, were donated by Dr. W. E. Castle at the University of California in Berkeley. Litters obtained by mating pairs of these animals ${ }^{3}$ regularly included one or more offspring with jaundice. Nonjaundiced litter mates and normal Wistar and Sprague-Dawley rats served as controls. Only male animals of at least 200 $\mathrm{Gm}$. body weight were used for the experiments. The rats were housed in specially built glass cages which

1 Presented at the annual meeting of the American Society for Clinical Investigation, Atlantic City, N. J., May, 1957.

2 Present address: Thorndike Memorial Laboratory, Boston City Hospital, Boston, Mass.

3 The authors are grateful to Mr. Samuel M. Poiley, Animal Production Section, National Institutes of Health, for his help and cooperation. permitted the separate collection of urine and feces (11) and were fed Purina laboratory chow.

Blood was removed from the tail or the subclavian veins for the following determinations: hemoglobin concentration (12), reticulocyte count (13), one minute directreacting and total serum bilirubin (14), and paper chromatographic analysis of the serum bilirubin azo derivatives (15). The urine was examined for bilirubin with the Harrison test (16) and by paper chromatographic analysis (15). Fecal urobilinogen excretion was estimated in stool samples collected over four consecutive days, and the values were expressed in mg. per day per $100 \mathrm{Gm}$. body weight (17).

$o$-Aminobenzoic acid and menthol were dissolved in 50 per cent ethanol and were administered by stomach tube in doses of $25 \mathrm{mg}$. per $100 \mathrm{Gm}$. body weight. During the 24 hour period immediately following the drug administration, the total urinary glucuronides were estimated (18) and expressed as glucuronic acid. For comparison, glucuronide excretion was determined during similar control periods when the rats were given only 50 per cent ethanol. Aqueous sodium $o$-aminobenzoate was injected intraperitoneally (100 mg. salt per $100 \mathrm{Gm}$. body weight) and urinary glucuronide excretion was estimated over a seven hour period immediately following the administration of the compound. The values obtained were compared with those found after injection of an equivalent amount of sodium chloride at the same hour of the preceding day. In all instances, the difference in the amount of glucuronic acid excreted during the test period and the control periods was expressed in per cent of the dose of $o$-aminobenzoic acid and of menthol administered. Sodium benzoate was injected intraperitoneally (50 mg. benzoic acid per $100 \mathrm{Gm}$. body weight) and the urinary excretion of hippurate was estimated over a 12 hour period, following the injection of the compound. The hippuric acid was extracted and crystallized (19), and the amino nitrogen of the crystals was determined by the micro-Kjeldahl method (20). Results were expressed in per cent of the dose of benzoic acid administered.

For estimation of enzymatic activity, the rats were decapitated and the livers were immediately chilled and homogenized with cold isotonic $\mathrm{KCl}$. Microsomes were prepared as described previously (21). Uridine diphosphate (UDP) glucose dehydrogenase activity in the liver was 
TABLE I

Serum bilirubin concentration in Wistar rats

\begin{tabular}{|c|c|c|c|c|c|}
\hline \multirow[b]{2}{*}{ Rats } & \multirow[b]{2}{*}{ No. } & \multicolumn{2}{|c|}{$\begin{array}{l}\text { One minute } \\
\text { direct-reacting }\end{array}$} & \multicolumn{2}{|c|}{ Total bilirubin } \\
\hline & & Mean & S.D.* & Mean & S.D. \\
\hline & & \multicolumn{2}{|c|}{$m g . \%$} & \multicolumn{2}{|c|}{$m g . \%$} \\
\hline Jaundiced & 14 & 0.21 & 0.05 & 8.09 & 2.85 \\
\hline $\begin{array}{l}\text { Nonjaundiced } \\
\text { litter mates }\end{array}$ & 5 & $<01$ & & $<0.1$ & \\
\hline Normal controls & 5 & $<0.1$ & & $<0.1$ & \\
\hline
\end{tabular}

* Standard deviation.

assayed by the method of Strominger, Maxwell, Axelrod, and Kalckar (21). The rate of formation of $o$-aminophenyl glucosiduronic acid (22) was determined by incubating microsomes obtained from one $\mathrm{Gm}$. of liver with 0.2 micromole of $o$-aminophenol and 0.3 micromole of UDP glucuronic acid which was prepared enzymatically (21). In the kidney, glucuronide formation was estimated by incubating tissue slices in Krebs-Ringer bicarbonate with 0 -aminophenol and UDP glucuronic acid (22).

For histological examination frozen sections were used, as well as paraffin sections of material that had been fixed in formalin or in Zenker's solution. The golden material found at the tip of the renal papilla of jaundiced animals was freed under a dissecting microscope and was dissolved in $0.2 \mathrm{ml}$. of chloroform. The azo derivatives prepared from this material were studied by paper chromatography (15).

For collection of bile, the rats were anesthetized with ether, the peritoneal cavity was opened by a midline incision, and the common bile duct was ligated in its distal portion. The dilated proximal part of the duct was then intubated with a polyethylene tube (outside diameter, 0.024 inch), which was anchored with a silk ligature. Bile flow at the rate of 0.8 to $1.0 \mathrm{ml}$. per hour was maintained by subcutaneous injection of $1.0 \mathrm{ml}$. normal saline per hour per $100 \mathrm{Gm}$. body weight. Aliquots of the bile were removed at different time intervals for estimation of bilirubin concentration (14) and for paper chromatographic analysis of the bilirubin azo derivatives (15).

Crystalline bilirubin (Armour and Company) was dissolved in $0.2 \mathrm{ml}$. of 2 per cent sodium carbonate, con-

TABLE II

Fecal urobilinogen excretion in Wistar rats

\begin{tabular}{|c|c|c|c|}
\hline \multirow[b]{2}{*}{ Rats } & \multirow[b]{2}{*}{ No. } & \multicolumn{2}{|c|}{ Urobilinogen } \\
\hline & & Mean & S.D. \\
\hline & & \multicolumn{2}{|c|}{$\begin{array}{c}\text { mg. } / \text { day } / 100 \mathrm{Gm} . \\
\text { body weight }\end{array}$} \\
\hline $\begin{array}{l}\text { Jaundiced } \\
\text { Nonjaundiced }\end{array}$ & 3 & 0.009 & 0.004 \\
\hline litter mates & 3 & 0.039 & 0.013 \\
\hline Normal controls & 4 & 0.077 & 0.024 \\
\hline
\end{tabular}

taining $0.05 \mathrm{ml}$. of $1 \mathrm{~N}$ sodium hydroxide. For intravenous injection, this solution was mixed with normal rat serum to give a final concentration of $1 \mathrm{mg}$. bilirubin per $\mathrm{ml}$. As source of bilirubin glucuronide, serum was collected from patients with complete biliary obstruction, or sterile bile was obtained from patients with a $\mathrm{T}$-tube in the common bile duct. Before these specimens were injected, their approximate concentration of conjugated bilirubin was estimated by the direct van den Bergh method (14) and by paper chromatography (15). Bromsulphalein ( $0.5 \mathrm{mg}$. per $100 \mathrm{Gm}$. body weight) was injected intravenously and the concentration of the dye in serum and bile was determined at different time intervals (23). Cholografin (iodopamide) was injected intravenously $(0.1 \mathrm{ml}$. per $100 \mathrm{Gm}$. body weight) and the excretion of the contrast medium into the duodenum was followed by serial X-rays.

\section{RESULTS}

\section{A. Hematological and pigmentary studies.}

Hematological studies, performed on 10 jaundiced rats, yielded a mean hemoglobin concentration of $13.2 \mathrm{Gm}$. per cent (S.D., $1.5 \mathrm{Gm}$. per cent) and a mean reticulocyte count of 0.69 per cent (S.D., 0.41 per cent). These values are within normal limits (24). The values for serum bilirubin concentration are summarized in Table I. On paper chromatographic analysis, the sera of jaundiced rats exhibited only the azo derivatives of free, nonconjugated bilirubin. In nonjaundiced litter mates and in normal control rats the plasma was colorless and bilirubin azo derivatives were not demonstrable on paper chromatography. Bilirubin could not be detected in the urine of any of the three groups of rats.

In the bile, the bilirubin concentration of five jaundiced rats was $3.32 \mathrm{mg}$. per cent (S.D., 1.04 mg. per cent). On paper chromatographic analysis, azo derivatives of bilirubin glucuronide could not be demonstrated, but there were small amounts of other azo derivatives, which exhibited Rf's similar to that of the azo derivatives of crystalline bilirubin. In addition, these bile specimens contained some yellow pigments which gave a negative van den Bergh reaction. In normal control rats and in nonjaundiced litter mates, virtually all of the pigment in the bile was present as bilirubin glucuronide.

As shown in Table II, fecal urobilinogen excretion was much smaller in jaundiced rats than in nonjaundiced animals. Patency of the biliary excretory apparatus was demonstrated by the ob- 
TABLE III

Urinary excretion of glucuronic acid after administration of o-aminobenzoic acid and of menthol to Wistar rats

\begin{tabular}{|c|c|c|c|c|c|c|}
\hline \multirow[b]{2}{*}{ Rats } & \multirow[b]{2}{*}{ No. } & \multirow[b]{2}{*}{ Compound given } & \multirow{2}{*}{$\begin{array}{l}\text { Dose given } \\
\text { per } 100 \mathrm{Gm} .\end{array}$} & \multirow{2}{*}{$\begin{array}{l}\text { Mode of ad- } \\
\text { ministration }\end{array}$} & \multicolumn{2}{|c|}{$\begin{array}{l}\text { Glucuronic acid excreted } \\
\text { in \% of dose administered* }\end{array}$} \\
\hline & & & & & Mean or range & S.D. \\
\hline Jaundiced & 4 & $\begin{array}{l}o \text {-aminobenzoic } \\
\text { acid }\end{array}$ & $\begin{aligned} m g . \\
25\end{aligned}$ & Oral & 22.8 & 2.1 \\
\hline $\begin{array}{l}\text { Nonjaundiced } \\
\text { litter mates }\end{array}$ & 9 & $\begin{array}{l}o \text {-aminobenzoic } \\
\text { acid }\end{array}$ & 25 & Oral & 70.1 & 16.4 \\
\hline Normal controls & 4 & $\begin{array}{l}o \text {-aminobenzoic } \\
\text { acid }\end{array}$ & 25 & Oral & 93.2 & 4.8 \\
\hline Jaundiced & 2 & $\begin{array}{l}\text { Sodium } \\
o \text {-aminobenzoate }\end{array}$ & 100 & Intraperitoneal & $8.4-10.9$ & \\
\hline $\begin{array}{l}\text { Nonjaundiced } \\
\text { litter mates }\end{array}$ & 4 & $\begin{array}{l}\text { Sodium } \\
o \text {-aminobenzoate }\end{array}$ & 100 & Intraperitoneal & 25.4 & 3.2 \\
\hline Jaundiced & 2 & Menthol & 25 & Oral & $28-42$ & \\
\hline $\begin{array}{l}\text { Nonjaundiced } \\
\text { litter mates }\end{array}$ & 2 & Menthol & 25 & Oral & $70-72$ & \\
\hline
\end{tabular}

* All values are corrected for basal glucuronide excretion.

servation that Cholografin ${ }^{\circledR}$ could be recognized in the duodenum 20 minutes after its intravenous injection. Furthermore, in two jaundiced rats in which bromsulphalein had been injected intravenously the dye was cleared from the plasma in 45 minutes, and was quantitatively recovered in the bile.

In three jaundiced rats, the urinary excretion of hippurate was 75 per cent (S.D., 2.2 per cent) of the administered dose of benzoate, while in three normal control animals the corresponding value was 57 per cent (S.D., 1.7 per cent).

\section{B. Glucuronide formation in vivo}

In 8 jaundiced rats, the basal urinary excretion of glucuronic acid amounted to $4.7 \mathrm{mg}$. per day (S.D., $1.3 \mathrm{mg}$.), while 24 determinations in 11 nonjaundiced animals gave a mean value of 9.6 mg. per day (S.D., $2.1 \mathrm{mg}$.). The difference in daily glucuronic acid excretion between nonjaundiced litter mates and normal control rats was statistically not significant. As seen in Table III, the urinary excretion of glucuronic acid following oral administration of $o$-aminobenzoic acid was much smaller in jaundiced rats than in nonjaundiced controls $(p<0.001)$. Similar observations were made after oral administration of menthol and after intraperitoneal injection of sodium $o$-aminobenzoate (Table III).

\section{Glucuronide formation in vitro.}

Data for the in vitro biosynthesis of UDP glucuronic acid from UDP glucose with hepatic UDP glucose dehydrogenase are given in Table IV. Data are also presented for the formation of $o$-aminophenyl glucosiduronic acid from $o$-aminophenol and UDP glucuronic acid by liver microsomes. UDP glucose dehydrogenase was found to be about equally active in the liver of all three groups of rats. On the other hand, the rate of

TABLE IV

Enzymatic synthesis of uridine diphosphate (UDP) glucuronic acid and of o-aminophenyl glucosiduronic acid by rat liver in vitro

\begin{tabular}{lcccc}
\hline \multicolumn{1}{c}{ Rats } & No. & $\begin{array}{c}\text { UDP } \\
\text { glucu- } \\
\text { ronic } \\
\text { acid } \\
\text { formed }\end{array}$ & $\begin{array}{c}\text { o-amino- } \\
\text { phenyl } \\
\text { glucosid- } \\
\text { uronic } \\
\text { acid } \\
\text { formed }\end{array}$ & $\mathrm{p}$ \\
\hline $\begin{array}{l}\text { Jaundiced } \\
\text { Nonjaundiced } \\
\text { litter mates }\end{array}$ & 6 & 4.9 & 0.008 & \\
$\begin{array}{l}\text { Sprague-Dawley } \\
\text { controls }\end{array}$ & 8 & 4.3 & 0.034 & $<0.001$ \\
\hline
\end{tabular}


formation of $o$-aminophenyl glucosiduronic acid by liver microsomes of jaundiced rats was much lower than that of nonjaundiced controls. A statistically significant difference was also found between nonjaundiced litter mates and normal Sprague-Dawley rats (Table IV). When equal amounts of liver microsomes from jaundiced Wistar rats and from normal Sprague-Dawley rats were mixed, no reduction in the rate of glucuronide formation of the latter was observed. With kidney slices, formation of small amounts of $o$-aminophenyl glucosiduronic acid was demonstrable in nonjaundiced rats, but none was detectable in jaundiced animals.

\section{Biliary excretion of injected pigment}

In Figure 1, typical data are presented on biliary bilirubin excretion in a $330 \mathrm{Gm}$. jaundiced rat, which had been given intravenous injections, first of $1.5 \mathrm{mg}$. crystalline bilirubin, and 30 minutes later of $0.8 \mathrm{mg}$. bilirubin glucuronide. The bile was collected before, during and after the injections over consecutive periods, ranging from 10 to 30 minutes. The serum bilirubin concentra-

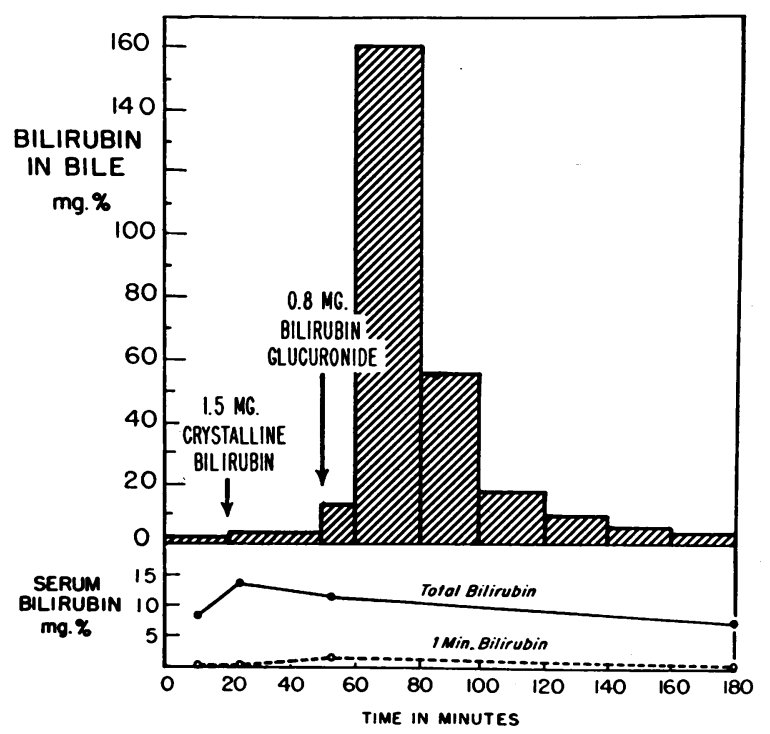

Fig. 1. Bilirubin Excretion in the Bile of a Jaundiced Rat After Intravenous Injections of BILIRUBIN

One and five-tenths mg. crystalline bilirubin and 0.8 mg. bilirubin glucuronide were injected in the tail vein of a $330 \mathrm{Gm}$. jaundiced Wistar rat. The conjugated bilirubin was rapidly excreted in the bile, while the injection of crystalline bilirubin resulted only in a slightly increased concentration of nonconjugated bilirubin. tion, determined prior to the injections, was 8.2 mg. per cent, all of which was present in the nonconjugative form. Immediately after the injection of crystalline bilirubin, the serum bilirubin level rose to $13.5 \mathrm{mg}$. per cent but it gradually fell to $11.6 \mathrm{mg}$. per cent after 30 minutes and to $7.1 \mathrm{mg}$. per cent after 160 minutes. The injection of bilirubin glucuronide increased the 1 minute directreacting serum fraction temporarily from 0.2 to $1.5 \mathrm{mg}$. per cent.

At the beginning of the observation period, the bilirubin concentration in the bile was $1.6 \mathrm{mg}$. per cent, none of which was bilirubin glucuronide. The injection of crystalline bilirubin was followed by an only slight increase in the concentration of nonconjugated bilirubin to $2.8 \mathrm{mg}$. per cent, but no glucuronide was demonstrable. After the injection of conjugated bilirubin, on the other hand, a rapid increase in biliary pigment excretion was observed, which during the second collection period, raised the bilirubin concentration in the bile approximately one hundred fold over the preinjection level. Virtually all of the excreted pigment was present in the form of the glucuronide. At the end of a two hour period, paper chromatographic analysis indicated that all the injected bilirubin glucuronide had been cleared from the plasma and that the bile no longer contained bilirubin glucuronide.

\section{E. Anatomical and histological findings}

At necropsy of jaundiced rats, icterus was particularly evident in the peritoneal lining and in the subcutaneous and mesenteric tissues. The liver was grossly and microscopically normal, and the extrahepatic bile ducts were patent and not distended. Fecal material in the lumen of the intestinal tract was of the normal brown color. No abnormal pigmentation could be recognized in the central nervous system.

The kidneys of all adult jaundiced rats exhibited a grossly demonstrable deposit of orange material at the tip of the renal papilla. On microscopic study of frozen sections, this material was shown to consist of many rhomboid and needle-like crystals which were deposited in the interstitial tissue, and which resembled bilirubin crystals (25) (Figure 2). The tubular epithelium was not pigmented. Paper chromatographic analysis of the 
azo derivatives prepared from the crystals (15) revealed them to consist of free, nonconjugated bilirubin. In some of the jaundiced rats, small numbers of similar crystals could occasionally be found in the adrenal medulla, in the brain, and in the mucosa of the intestinal tract.

Nonjaundiced litter mates and normal control rats showed no anatomical or histological abnormalities.

\section{DISCUSSION}

Malloy and Loewenstein, in studying the jaundice of this mutant strain of Wistar rats, concluded that the icterus was not hemolytic in nature (10). This is confirmed by the present investigation which revealed normal values for hemoglobin concentration (24) and reticulocyte counts and reduced fecal urobilinogen excretion. That the jaundice was not obstructive in nature was indicated by the absence of conjugated bilirubin in the plasma and of bilirubin excretion in the urine (15). Furthermore, the efficiency with which injected bromsulphalein, Cholografin ${ }^{\circledR}$ and conjugated bilirubin were excreted in the bile demonstrated that the hepatic excretory apparatus was functioning normally and that the biliary ductal system was patent.

The retention of free bilirubin in the plasma associated with reduced excretion of fecal urobilino-

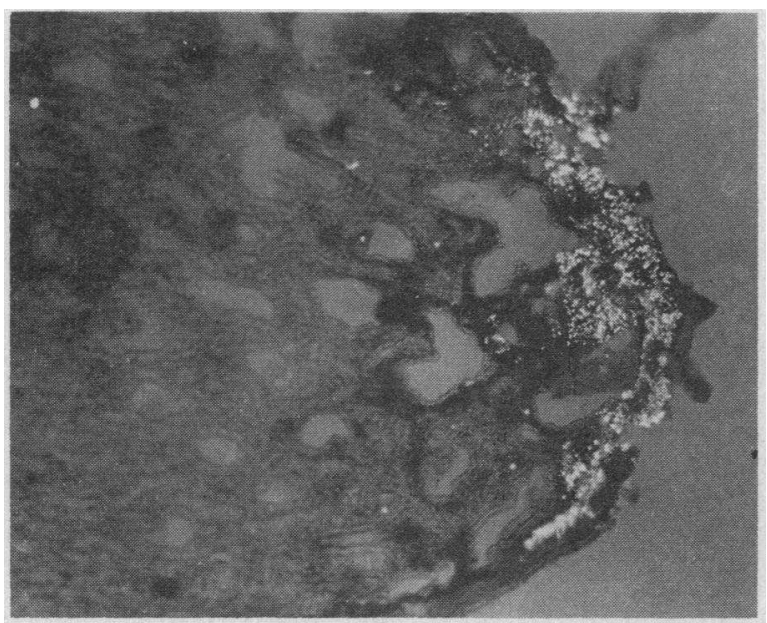

Fig. 2. Bilirubin in the Renal Papilla of a JaunDICED RAT

Frozen section, photographed with polarized light at partial extinction. The light areas represent bilirubin crystals, the dark ones amorphous precipitates of bilirubin (magnification times 75 ). gen was suggestive of a defect in the glucuronide forming mechanism (26). In the jaundiced rats, such a defect in glucuronide formation has been demonstrated in vitro and in vivo. In vitro, it was found that while UDP glucuronic acid, the glucuronic acid donor, was formed at a normal rate, the liver microsomes were deficient in the enzyme system, which transfers the glucuronic acid to suitable aglycones. As a result of this enzymatic defect, the rate of glucuronide formation in the liver was much reduced as compared to normal control rats but it was not entirely absent. The results obtained by mixing liver microsomes of jaundiced and of nonjaundiced animals, indicated that reduction in glucuronide formation was not due to the presence of enzyme inhibitors. These findings differ from a recent report by Carbone and Grodsky (27), who stated that in jaundiced rats "glucuronyl transferase activity is absent or inhibited." The presence of a defect in glucuronide formation in these jaundiced rats had recently been confirmed by Lathe and Walker (28).

In vivo, jaundiced rats were shown to excrete less glucuronic acid than nonjaundiced animals under basal conditions. Similarly, jaundiced rats responded to loading doses of aglycones with smaller increases in glucuronic acid excretion than normal animals and nonjaundiced litter mates.

In view of these findings, one might have anticipated that the formation of bilirubin glucuronide would proceed at a similarly reduced rate, but would not be entirely absent. It was therefore surprising to find that on paper chromatographic analysis, bile from jaundiced rats consistently failed to reveal even trace amounts of bilirubin glucuronide. On the other hand, small amounts of nonconjugated bilirubin were regularly demonstrable in such specimens.

Two explanations are offered to account for these observations. Since it appears that a single enzyme system is involved in all types of glucuronides formed (29), it is possible that bilirubin is unsuccessful in competing with other normally occurring aglycones for the deficient glucuronic acid transferase system (8). If this hypothesis is correct, it must be assumed that small amounts of free bilirubin probably attached to proteins are capable of leaking from the extracellular fluid into the bile. Another and more likely explanation is 
that in jaundiced rats, small amounts of bilirubin glucuronide are actually formed, but are rapidly hydrolyzed after their excretion into the bile, and thus escape chromatographic identification.

Regardless of which of these two explanations is correct, it is evident that in the absence of an efficiently functioning mechanism for glucuronide formation, biliary bilirubin excretion is severely impaired. This was apparent from the lower bilirubin concentration in the bile and the reduced urobilinogen excretion in the feces of jaundiced rats as compared to normal rats (30). More important, however, is the observation that in jaundiced rats injected bilirubin glucuronide was rapidly excreted in the bile, whereas free bilirubin was not. The intravenous administration of crystalline bilirubin to jaundiced rats resulted in the excretion of less than 1 per cent of the amount of pigment that was excreted by normal rats with a comparable serum bilirubin level (31). On the other hand, injection of conjugated bilirubin was followed by a more than one hundred fold increase in biliary pigment excretion. The maximal clearance for bilirubin glucuronide in jaundiced rats was similar to the maximal clearance for crystalline bilirubin in normal rats as determined by Weinbren and Billing (31).

In the mammalian organism, most metabolites which are excreted in conjugated form can combine with more than one hydrophilic group (32, 33). The finding that in jaundiced rats a larger fraction of the injected benzoate was converted to hippurate than in normal rats, is believed to indicate that the defect in glucuronide formation may in part be compensated by activation of other detoxication mechanisms. In the present study, however, no such compensatory mechanism has been demonstrated for the conjugation of bilirubin. Although normal rat bile regularly contained small amounts of water-soluble, diazo-positive pigments of a nonglucuronide nature, this pigment fraction was not increased in jaundiced rats. It is surprising that in spite of the severe impairment in pigment excretion, the physiological turnover of heme compounds did not result in a steadily increasing degree of jaundice. It would appear that alternative pathways of heme metabolism must exist to account for the lack of progressivly increasing icterus in these animals (4). 'This may also ex- plain the observation that after the injection of crystalline bilirubin to jaundiced rats (Figure 1), the concentration of free bilirubin in the serum decreased much more rapidly than could be accounted for by the excretion of pigment in the bile. It is realized, however, that this fall in serum bilirubin concentration may in part have been due to redistribution of pigment in the extravascular space (34).

Since breeding of nonjaundiced litter mates produced offspring which were in part jaundiced, it may be assumed that such rats were carriers of the jaundice trait. Although their serum bilirubin levels were not elevated, their rate of glucuronide formation was reduced as compared to normal Wistar and Sprague-Dawley rats, but it was greater than in jaundiced animals. This would suggest that in nonjaundiced litter mates the metabolic abnormality is less severe than in jaundiced rats and is insufficient to produce pigment retention in the serum. Since it has been observed that significant differences in glucuronide metabolism exist between the two sexes in rats (35), only male animals have been used in the present study. Because of this limitation and the relatively small number of animals studied, the available data are believed to be insufficient to establish the genetic pattern of this disorder.

In the plasma, nonconjugated bilirubin is attached to proteins, mainly albumin (36), which keeps it in solution, since at physiological $\mathrm{pH}$ it is almost insoluble in water (37). In the tissues, on the other hand, information is lacking as to whether bilirubin is attached to extravascular serum albumin or to other tissue proteins. The presence of bilirubin crystals in the renal papilla and in other organs of jaundiced rats seems to indicate that the local concentration of bilirubin must have exceeded the capacity to bind the pigment. It is of interest to note that in conditions associated with high concentrations of nonconjugated bilirubin in man, bilirubin crystals in tissues have also been observed (25). In three patients with congenital nonhemolytic jaundice (9), which is believed to be due to a defect in glucuronide formation $(7,8)$, Smith, Wheeler, Bauer, and Saltzstein have found bilirubin crystals in the renal papillae (38). The significance of these observations must be clarified by further studies. 


\section{SUMMARY}

1. Wistar rats of a mutant strain, exhibiting congenital jaundice, were studied. The icterus was shown to be nonhemolytic and nonobstructive in nature.

2. In jaundiced rats, no bilirubin glucuronide was demonstrable in serum, bile or urine. The bile contained small amounts of free bilirubin. Fecal urobilinogen excretion was greatly reduced.

3. The liver was histologically normal, and liver function tests, such as hippuric acid formation and excretion of bromsulphalein, Cholografin ${ }^{\circledR}$ and conjugated bilirubin were normal.

4. In vivo and in vitro, marked impairment in glucuronide formation was demonstrated in jaundiced rats, due to a defect in the glucuronyl transferase system. Since conjugation of bilirubin appears to be essential for its excretion in the bile, this enzymatic defect in glucuronide formation is believed to be the cause for the impaired pigment excretion and the retention of free bilirubin in the plasma.

5. Nonjaundiced litter mates of icteric rats were found to have a reduced ability to form glucuronides, but the defect was less severe than in jaundiced animals and did not result in retention of bilirubin in the plasma.

6. Crystals consisting of nonconjugated bilirubin were observed in the renal papilla and in other organs of jaundiced rats.

\section{REFERENCES}

1. Schmid, R. Direct-reacting bilirubin, bilirubin glucuronide, in serum, bile and urine. Science 1956, 124, 76.

2. Billing, B. H., and Lathe, G. H. The excretion of bilirubin as an ester glucuronide, giving the direct van den Bergh reaction. Biochem. J. 1956, 63, $6 \mathrm{p}$.

3. Talafant, E. Properties and composition of the bile pigment, giving a direct diazo reaction. Nature (Lond.) 1956, 178, 312.

4. Schmid, R. Some aspects of bile pigment metabolism. Clin. Chem. 1957, 3, 394.

5. Billing, B. H., and Lathe, G. H. Bilirubin metabolism in jaundice. Amer. J. Med. 1958, 24, 111.

6. Schmid, R., Hammaker, L., and Axelrod, J. The enzymatic formation of bilirubin glucuronide. Arch. Biochem. 1957, 70, 285.

7. Schmid, R., Axelrod, J., Hammaker, L., and Rosenthal, I. M. Congenital defects in bilirubin metabolism (abstract). J. clin. Invest. 1957, 36, 927.
8. Axelrod, J., Schmid, R., and Hammaker, L. A biochemical lesion in congenital, non-obstructive, nonhaemolytic jaundice. Nature (Lond.) 1957, 180, 1426.

9. Crigler, J. F., Jr., and Najjar, V. A. Congenital familial nonhemolytic jaundice with kernicterus. Pediatrics 1952, 10, 169.

10. Malloy, H. T., and Loewenstein, L. Hereditary jaundice in rat. Canad. med. Ass. J. 1940, 42, 122.

11. Draper, H. H., and Robbins, A. F. A urinofecal separator for laboratory rat. Proc. Soc. exp. Biol. (N. Y.) $1956,91,174$

12. Sunderman, F. W., MacFate, R. P., MacFayden, D. A., Stevenson, G. F., and Copeland, B. E. Clinical Hemoglobinometry. Baltimore, The Williams and Wilkins Company, 1953.

13. Brecher, G. New methylene blue as a reticulocyte stain. Amer. J. clin. Path. 1949, 19, 895.

14. Ducci, H., and Watson, C. J. The quantitative determination of the serum bilirubin with special reference to the prompt-reacting and the chloroform-soluble types. J. Lab. clin. Med. 1945, 30, 293.

15. Schmid, R. The identification of "direct-reacting" bilirubin as bilirubin glucuronide. J. biol. Chem. 1957, 229, 881.

16. Hawkinson, V., Watson, C. J., and Turner, R. H. Modification of Harrison's test for bilirubin in the urine especially suited for mass and serial use. J. Amer. med. Ass. 1945, 129, 514.

17. Schwartz, S., Sborov, V., and Watson, C. J. Studies of urobilinogen. IV. The quantitative determination of urobilinogen by means of the Evelyn photoelectric colorimeter. Amer. J. clin. Path. 1944, 14, 598.

18. Dische, Z. A new specific color reaction of hexuronic acids. J. biol. Chem. 1947, 167, 189.

19. Quick, A. J. The study of benzoic acid conjugation in the dog with a direct quantitative method for hippuric acid. J. biol. Chem. 1926, 67, 477.

20. Ma, T. S., and Zuazaga, G. Micro-Kjeldahl determination of nitrogen. Industr. engin. Chem. (Analyt. Ed.) 1942, 14, 280.

21. Strominger, J. L., Maxwell, E. S., Axelrod, J., and Kalckar, H. M. Enzymatic formation of uridine diphosphoglucuronic acid. J. biol. Chem. 1957, 224, 79.

22. Levvy, G. A., and Storey, I. D. E. The measurement of glucuronide synthesis by tissue preparations. Biochem. J. 1949, 44, 295.

23. Gaebler, O. H. Determination of bromsulphalein in normal, turbid, hemolyzed or icteric serums. Amer. J. clin. Path. 1945, 15, 452.

24. Wintrobe, M. M. Clinical Hematology, 3rd ed. Philadelphia, Lea and Febiger, 1951.

25. Dunn, T. B. Hematoidin crystals in reticulum cell sarcoma of the mouse and in newborn human tissues. Milit. Surg. 1951, 109, 350. 
26. Schmid, R. Neuere Gesichtspunkte auf dem Gebiete des Gallenfarbstoff wechsels. Helv. med. Acta 1957, 24, 273.

27. Carbone, J. V., and Grodsky, G. M. Constitutional nonhemolytic hyperbilirubinemia in the rat: Defect of bilirubin conjugation. Proc. Soc. exp. Biol. (N. Y.) 1957, 94, 461.

28. Lathe, G. H., and Walker, M. An enzymatic defect in human neonatal jaundice and in Gunn's strain of jaundiced rats. Biochem. J. 1957, 67, 9 p.

29. Axelrod, J., Inscoe, J., and Tomkins, G. M. The enzymatic formation of $\mathrm{N}$-glucuronocyl acids. $\mathrm{J}$. biol. Chem. In press.

30. Hanzon, V. Liver cell secretion under normal and pathologic conditions studied by fluorescence microscopy on living rats. Acta physiol. scand. 1952, 28, Suppl. 101.

31. Weinbren, K., and Billing, B. H. Hepatic clearance of bilirubin as an index of cellular function in the regenerating rat liver. Brit. J. exp. Path. 1956, 37, 199.

32. Williams, R. T. Detoxication Mechanisms. New York, John Wiley and Sons, 1947.

33. Quick, A. J. The conjugation of benzoic acid in man. J. biol. Chem. 1931, 92, 65.

34. Dragstedt, C. A., and Mills, M. A. The removal of intravenously injected bilirubin from the blood stream in the dog. Amer. J. Physiol. 1937, 119, 713.

35. Axelrod, J. Unpublished observations.

36. Klatskin, G., and Bungards, L. Bilirubin-protein linkages in serum and their relation to the van den Bergh reaction. J. clin. Invest. 1956, 35, 537.

37. Overbeek, J. T. G., Vink, G. L. J., and Deenstra, H. The solubility of bilirubin. Rec. Trav. chim. PaysBas 1955, 74, 81.

38. Smith, M. G., Wheeler, J. D., Bauer, W. C., and Saltzstein, S. L. Personal communication. 